\title{
B-type natriuretic peptide versus amino terminal pro-B type natriuretic peptide: selecting the optimal heart failure marker in patients with impaired kidney function
}

\author{
Lena Jafri ${ }^{1}$, Waqar Kashif ${ }^{2}$, Javed Tai ${ }^{2}$, Imran Siddiqui ${ }^{1}$, Iqbal Azam ${ }^{3}$, Hira Shahzad ${ }^{4}$ and Farooq Ghani ${ }^{1 *}$
}

\begin{abstract}
Background: The effect of impaired kidney function on B-type natriuretic peptide (BNP) and N-terminal proBNP (NT-proBNP) is vague. This study was performed to examine the effect of kidney dysfunction on the afore-mentioned markers and determine appropriate cutoffs for systolic heart failure (SHF).

Methods: In this cross sectional study adults with estimated glomerular filtration rate (eGFR) $<60 \mathrm{ml} / \mathrm{min}$ for $\geq 3$ months were identified in consulting clinics from June 2009 to March 2010. SHF was defined as documented by a cardiologist with ejection fraction of $<40 \%$ and assessed by New York Heart Association classification (NYHA). Plasma was assayed for creatinine (Cr), BNP and NT-proBNP.

Results: A total of 190 subjects were enrolled in the study, 95 with and 95 without SHF. The mean age of patients was $58( \pm 15)$ years, $67.4 \%$ being males. Mean BNP levels showed a 2.5 fold and 1.5 fold increase from chronic kidney disease (CKD) stage 3 to stage 5 in patients with and without SHF respectively. NT-proBNP levels in non-heart failure group were 3 fold higher in CKD stage 5 compared to stage 3. Mean NT-proBNP levels were 4 fold higher in CKD stage 5 compared to stage 3 in patients with SHF. Optimal BNP and NT-proBNP cutoffs of SHF diagnosis for the entire CKD group were $300 \mathrm{pg} / \mathrm{ml}$ and $4502 \mathrm{pg} / \mathrm{ml}$ respectively.

Conclusion: BNP and NT-proBNP were elevated in kidney dysfunction even in the absence of SHF; however the magnitude of increase in NT-proBNP was greater than that of BNP. BNP and NT-proBNP can be useful in diagnosing SHF, nonetheless, by using higher cutoffs stratified according to kidney dysfunction. NT-proBNP appears to predict heart failure better than BNP.
\end{abstract}

Keywords: B-Type natriuretic peptide, Heart failure, NT-proBNP, Kidney

\section{Background}

Literature from the United States, Australia and China report the prevalence of chronic kidney disease (CKD) as ranging from $11-13.1 \%$ [1-4]. Community based studies in Pakistan reveal a high burden of CKD ranging from 15 to $20 \%$ in subjects older than 40 years of age [5]. The exact prevalence of CKD in Pakistan is still unknown due to lack of documentation and funds, but it is expected to be high, with respect to the observation of

\footnotetext{
* Correspondence: farooq.ghani@aku.edu

'Department of Pathology \& Microbiology, Aga Khan University, Stadium Road, P.O. Box 3500, Karachi 74800, Pakistan

Full list of author information is available at the end of the article
}

the epidemic of diabetes and hypertension in this part of the world [6-8]. The prevalence of heart failure increases as glomerular filtration rate (GFR) declines and as many as $35 \%$ of patients reaching end stage renal disease already have clinical evidence of heart failure [9]. To prevent the occurrence of heart failure a reliable marker for observing cardiac overload in such patients is needed. The B-type natriuretic peptide (BNP) and $\mathrm{N}$ - terminal pro-hormone B-type natriuretic peptide (NT-proBNP) are established heart failure markers but concomitant presence of CKD changes their interpretation in significant manner [10-13].

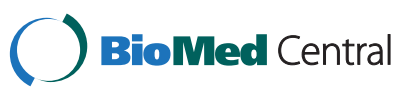


The source of BNP and NT-proBNP are mainly left ventricular myocytes. Distention of cardiac ventricle is considered the main stimulus for release of proBNP ${ }_{1-108}$. This pro-hormone is released into the circulation and is proteolytically cleaved into the biologically active $\mathrm{BNP}_{1-32}$ and the inactive NT-proBNP ${ }_{1-76}$. The understanding of the cleavage of proBNP in circulation is most likely by the pro-protein convertases corin and furin $[14,15]$. The processing of proBNP is indeed complex, with significant release of unprocessed proBNP, particularly in heart failure. Several recent studies have demonstrated that there are only small amounts of intact BNP in blood, and the major circulating forms of BNP are degradation products. These degradation products and intact proBNP are detected by BNP assays to a varying extent [16]. The synthesis and release of BNP is controlled at the level of gene expression which is predominantly controlled by ventricular hypertrophy, inflammation or stretch [17]. The clearance mechanism of BNP is through the endocytosis followed by lysosomal degradation, and through the degradation by the nonspecific membrane-bound enzyme neutral endopeptidase but NT-proBNP is mainly cleared via the kidneys [18-20]. Both are released in a 1:1 ratio but levels of NT-proBNP are higher than that of BNP because of halflife of 15-20 minutes whereas the half-life of NT-proBNP has been estimated to be longer (1-2 hours) [21,22].

We presume that with declining kidney function. NTproBNP would be affected more as compared to BNP. The ideal natriuretic peptide to diagnose heart failure in CKD remains undecided. This study was conducted to evaluate the effects of compromised kidney function on natriuretic peptides (BNP or NT-proBNP) and to determine optimal cutoffs predictable of systolic heart failure (SHF).

\section{Methods}

\section{Study population and procedure}

A cross-sectional study was conducted in the Section of Chemical Pathology, Department of Pathology and Microbiology in collaboration with the nephrology and cardiac units of Aga Khan University, Karachi Pakistan. It was conducted over a period of 10 months from June 2009 to March 2010. The Aga Khan University's Ethical Review Committee approved all investigational procedures involved in the study (reference number: 1054-Path-ERC-08). Recruitment of consecutive adult ambulatory subjects with impaired kidney function was carried out via nonprobability quota sampling from the clinics. After taking informed consent a proforma was filled including patient demographics, clinical history, smoking history, history of alcohol intake and drug history. The patient's body weight and height were recorded in order to determine the body mass index (BMI).

Impaired kidney function was taken as estimated glomerular filtration rate (eGFR) of $\leq 60 \mathrm{ml} / \mathrm{min}$. The
Cockcroft Gault equation was used to estimate the GFR of the study subjects from plasma creatinine $(\mathrm{Cr})$, age and body weight of the subjects [23]. The subjects stratification was carried out into CKD stage 3 (eGFR 30$60 \mathrm{ml} /$ minute), stage 4 (eGFR 15-29 ml/minute), and stage 5 (eGFR $<15 \mathrm{ml} /$ minute) [24]. Patients were classified as having SHF as per the interview data and physical examination using New York Heart Association (NYHA) and then reconfirmed from past echocardiography report (ejection fraction $<40 \%$ ) or SHF documented on the file by a cardiologist [25]. Patients on dialysis therapy and obese patients with body mass index $>30 \mathrm{~kg} / \mathrm{m}^{2}$ were not included in this study. Both endogenous and exogenous hormones have shown to induce elevated levels of BNP/NT-proBNP in circulation therefore pregnant females, those on hormonal therapy or taking contraceptives were also not included in this study group $[26,27]$. Six milliliter of blood sample was taken from every participating patient into vacutainers containing ethylene diamine tetra acetic acid (EDTA) for analysis. Plasma was obtained after centrifugation of samples for analyzing BNP, NT-proBNP and creatinine.

\section{Biochemical measurements}

Plasma samples were collected after informed consent and centrifuged at $3000 \mathrm{~g}$ for 10 minutes, aliquoted, frozen and maintained at $-80^{\circ} \mathrm{C}$. All samples were run in batches for plasma BNP, NT-pro BNP and Cr. The BNP levels were measured by automated electrochemiluminescence immunoassay (ECLIA) on Axym analyzer (Abbott diagnostic). The NT-proBNP levels were measured by automated ECLIA on Elecsys analyzer (Roche diagnostic). Plasma $\mathrm{Cr}$ levels were assayed with the rate-Jaffe reaction (with a calibrator traceable to the isotope dilution mass spectrometry reference method) on Synchron analyzer (Beckman Coulter). To ensure quality, normal and abnormal controls were run with every batch of BNP, NT-proBNP and $\mathrm{Cr}$ analysis.

\section{Statistical analysis}

Data analysis was performed using SPSS version 19. After checking for normality using the KolomogorovSmirnove test, BNP and NT-proBNP values were log transformed. Mean and \pm standard deviation (SD) or median with $25^{\text {th }}$ to $95^{\text {th }}$ percentile for continuous variables were computed. Dichotomous variables were expressed in percentages. The differences between groups were tested using $t$-test, one way analysis of variance (ANOVA) or Chi square test, as applicable. Post-hoc comparisons of log BNP/NT-proBNP in different groups were carried out using Bonferroni method. Variables used in univariate analysis with $p$-value of $<0.2$ were then entered in a multiple regression model using ENTER method. Results were reported as standardized $ß$-coefficient. Receiver operating 
characteristic (ROC) curves were constructed and areas under the curve (AUC) calculated for BNP and NTproBNP to detect SHF. Compromising on sensitivity in order to improve the specificity the uppermost corner on the left side of the ROC curve was not used for calculating cutoffs. A $p$-value of $<0.05$ was treated as significant in all above statistical analysis.

\section{Results}

\section{Study population}

Table 1 depicts the characteristics, medical history and biochemical results of one hundred and ninety study subjects enrolled in this study. The EF of all the study subjects was available. The mean age of the study population was $58 \pm$ 15 years and the majority was males (67.4\%). The median duration of impaired kidney function in subjects with impaired kidney function with and without SHF was 18 months (Interquartile Range $=3-160$ months) and 24 months (Interquartile Range $=6-190$ months) respectively ( $p$-value $>0.05$ ). Statistically non-significant difference existed between mean log BNP/NT-proBNP amongst males and females in those with and without SHF ( $p$-value >0.05).

\section{Multivariate predictors of natriuretic peptides}

The following predictor variables were used in univariate analysis taking log BNP/log NT-proBNP as the dependent

Table 1 Clinical characteristics and biochemical data of patients with impaired kidney function stratified into two groups based on cardiac function

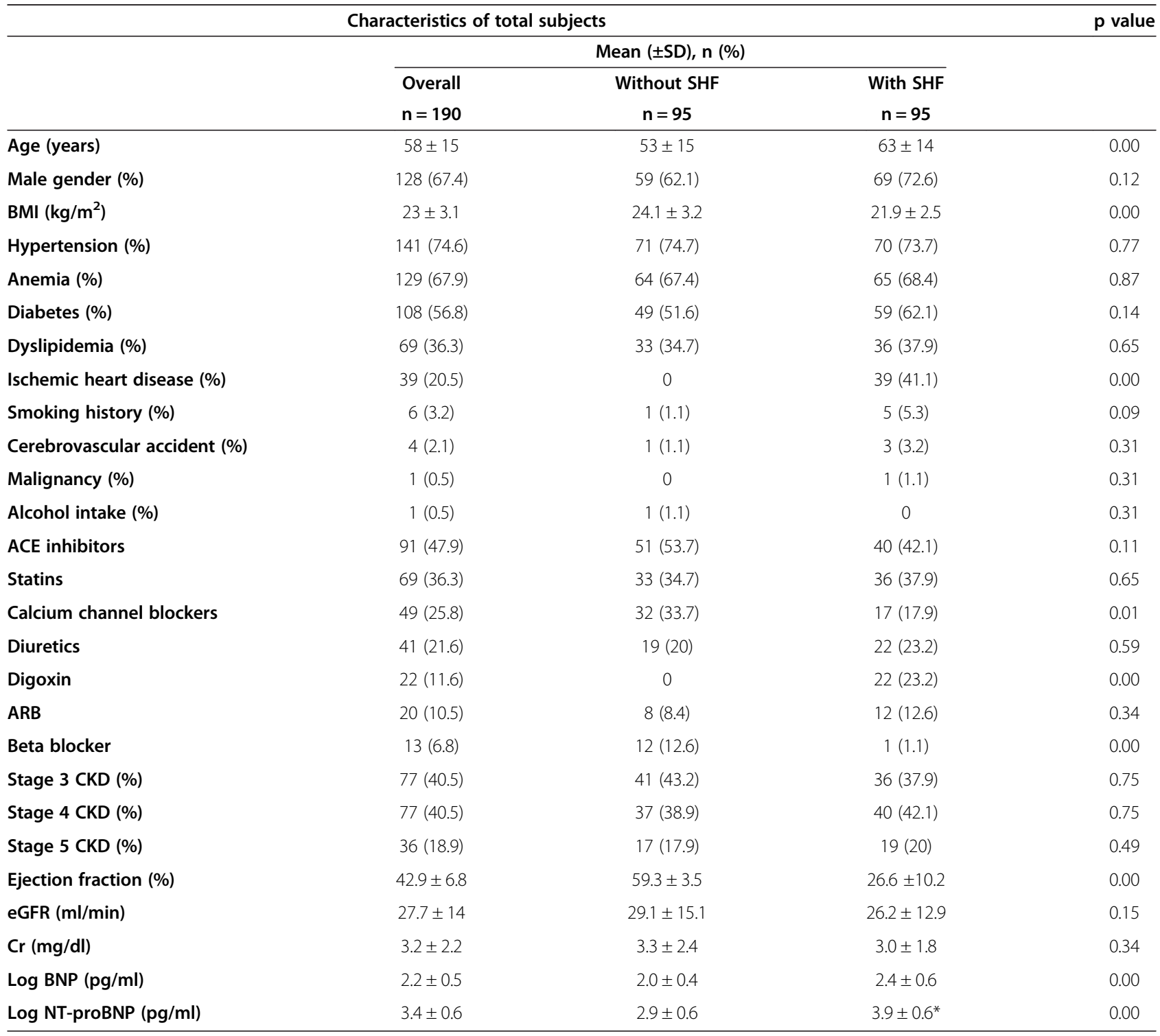

Abbreviations: SHF systolic heart failure, $S D$ standard deviation, $B M I$ body mass index, $A C E$ angiotensin converting enzyme, $A R B$ angiotensin receptor blocker, $C K D$ chronic kidney disease, eGFR estimated glomerular filtration rate, $C r$ creatinine, BNP b type natriuretic peptide, NT-proBNP Amino terminal B-type natriuretic peptide. 
Table 2 Predictors of log NT-proBNP in multivariate regression analysis

\begin{tabular}{|c|c|c|c|c|c|c|}
\hline \multirow[t]{2}{*}{ Variables } & \multicolumn{3}{|c|}{ Predictors of log BNP } & \multicolumn{3}{|c|}{ Predictors of log NT-proBNP } \\
\hline & $\begin{array}{c}\text { B standardized } \\
\text { coefficient }\end{array}$ & $\begin{array}{c}\text { Confidence } \\
\text { Interval }\end{array}$ & $p$ value & $\begin{array}{c}\text { B standardized } \\
\text { coefficient }\end{array}$ & $\begin{array}{c}\text { Confidence } \\
\text { Interval }\end{array}$ & $\mathrm{p}$ value \\
\hline Age & 0.055 & -0.003 to 0.007 & 0.40 & -0.108 & -0.011 to 0.000 & 0.03 \\
\hline Creatinine & -0.030 & -0.054 to 0.038 & 0.74 & -0.079 & -0.085 to 0.024 & 0.26 \\
\hline Body Mass Index & 0.008 & -0.014 to 0.031 & 0.46 & 0.104 & 0.003 to 0.053 & 0.02 \\
\hline Duration of kidney disease & 0.095 & 0.000 to 0.004 & 0.12 & -0.029 & -0.003 to 0.002 & 0.53 \\
\hline Heart Failure & -0.134 & -0.445 to 0.147 & 0.32 & 0.262 & 0.077 to 0.800 & 0.01 \\
\hline NYHA stage & 0.075 & -0.089 to 0.165 & 0.55 & 0.634 & 0.368 to 0.617 & 0.00 \\
\hline Ejection fraction & 0.045 & -0.008 to 0.010 & 0.76 & 0.138 & -0.004 to 0.017 & 0.22 \\
\hline eGFR & 0.070 & -0.005 to 0.011 & 0.48 & -0.468 & -0.036 to -0.019 & 0.00 \\
\hline Log BNP/NT-proBNP & 0.729 & 0.358 to 0.615 & 0.00 & 0.468 & 0.341 to 0.595 & 0.00 \\
\hline
\end{tabular}

Abbreviations: BNP b-type natriuretic peptide, NT-proBNP amino terminal B-type natriuretic peptide, NYHA New York Heart Association, eGFR estimated glomerular filtration rate, $A R B$ angiotensin receptor blocker.

p-value $<0.05$ statistically significant.

variables: age, gender, BMI, eGFR, ejection fraction, diabetes, hypertension, ischemic heart disease, cerebrovascular accident, dyslipidemia, anemia, smoking history, calcium channel blockers, beta-blockers, statins, digoxin, angiotensin converting enzyme inhibitor, angiotensin receptor blocker, diuretics and duration of kidney disease. Table 2 shows the final multivariate regression model for both BNP and NT-proBNP based on total number of subjects. Significant predictors of log NT-proBNP were found to be age, BMI, SHF, NYHA stage, and eGFR. Concentration of NT-proBNP increased progressively with declining kidney function estimated as eGFR. The log BNP and log NT-proBNP showed inverse correlation with EF $(r=-0.3$ and -0.6 respectively). Both BNP and NT-proBNP significantly correlated with NYHA functional classification.

Comparison of natriuretic peptides in NYHA groups

According to NYHA classification $35.8 \%$ were in NHYA 1, $19.5 \%$ in NYHA 2, 30\% in NYHA 3 and 14.7\% belonged to NYHA 4. Median BNP in these four classes were 80.8 (42.6-163.2), 200 (118.7-331), 478 (144.1 - 742.7), and 409.4 (285.8-720.3) pg/ml respectively. Post-hoc test was applied for multiple comparisons, using Bonferroni alpha (0.05), which revealed significant differences in log BNP between NYHA Class I, II and III whereas differences were non- significant between NYHA Class III and IV. Median log NT-proBNP in NYHA classes were 535.1 (191.9- 876.), 4192 (1505.8-7105), 13831 (4640.5-31230.5) and 22520 (9693.2-35000) pg/ml respectively. There was a significant mean difference in ANOVA results between log NT-proBNP levels amongst all the four classes of NYHA classification ( $p$-value $<0.05$ ). A progressive decline in eGFR with a rise in NYHA class was noted $(\mathrm{r}=-0.2$, $p$-value $<0.05)$.
Renal dysfunction and natriuretic peptides

Both natriuretic peptides showed rising trend as eGFR declined as depicted in Figure 1. Median BNP values in CKD 3,4 and 5 were 106.3 (43.1 - 281.6), 266.6 (108.9 - 589.3) and 328.9 (142.1 - 650.6) pg/ml respectively. Median NTproBNP values in CKD 3, 4 and 5 were 799 (227 - 5230), 5004 (905.5 - 14776.5), and 11215.5 (3532.5 - 35000) pg/ $\mathrm{ml}$ respectively.

Plasma BNP and NT-proBNP levels increased stepwise as kidney function deteriorated and the levels were significantly higher as the SHF worsened (Figure 2A and B). Highest BNP levels were noted in CKD stage 5 along with NYHA class 3 and highest NT-proBNP concentration was noted in CKD stage 5 along with NYHA class 3.

A continuous relationship of both peptides was revealed by head to head comparison of log BNP and log NT-

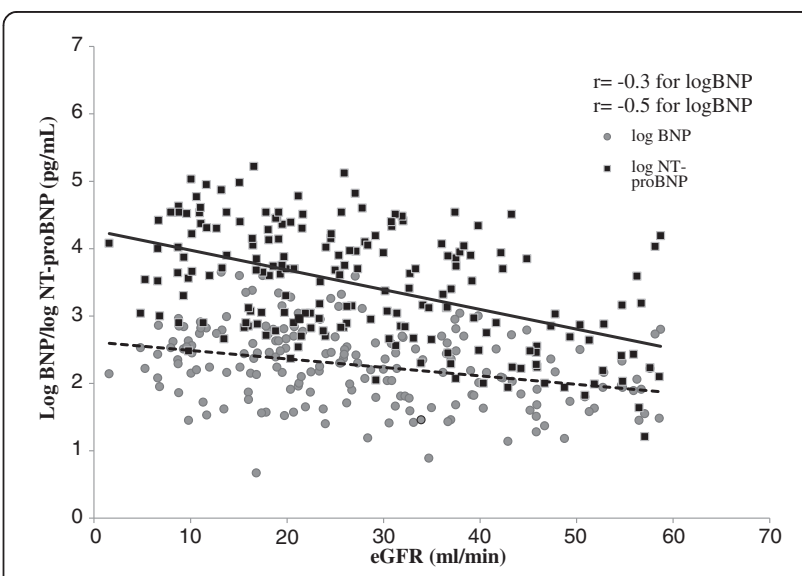

Figure 1 Scatter plot of log transformed plasma B-type natriuretic peptide (BNP) and amino terminal B-type natriuretic peptide (NT-proBNP) in relation to estimated glomerular filtration rate (eGFR). Lines of best linear fit are drawn. 


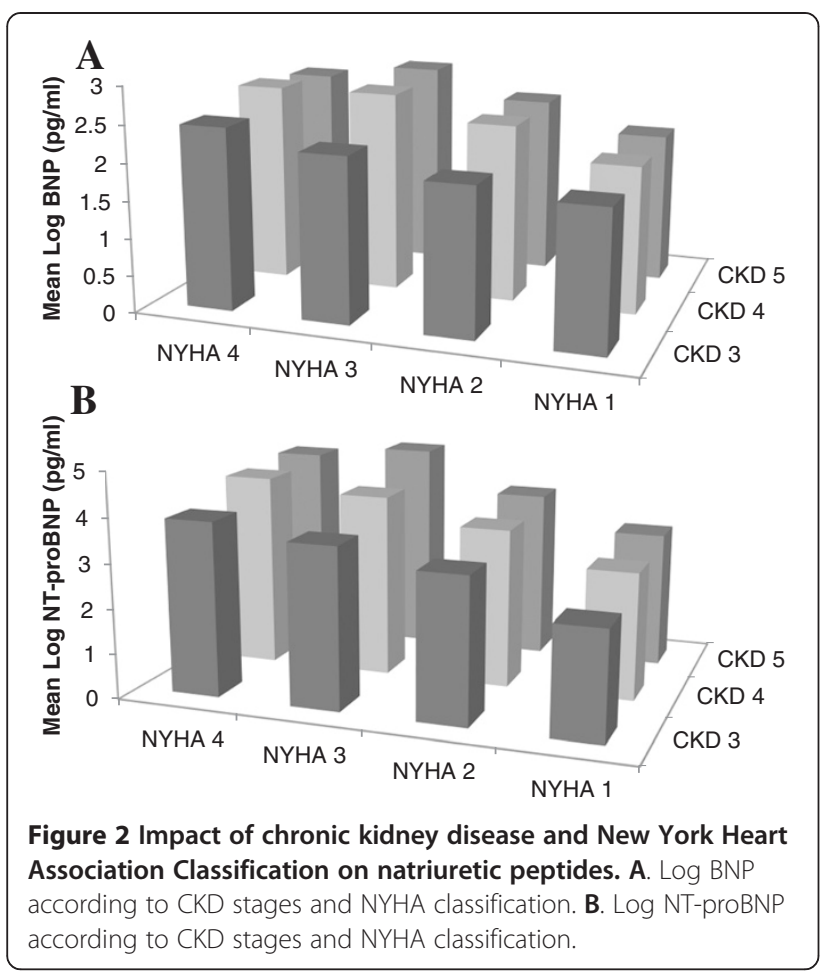

proBNP in the total group of patients. Log transformed BNP levels correlated with log transformed NT-proBNP levels $(\mathrm{r}=0.43, p$-value $<0.05)$. The association of BNP with NT-proBNP was higher in those suffering from kidney dysfunction alone without SHF $(\mathrm{r}=0.7, p$-value $<0.05)$ compared to those suffering from kidney dysfunction and SHF $(r=0.55, p$-value $<0.05)$. Non-significant correlation with each other was shown by both peptides in the group with SHF along with CKD 5.

Concentration of BNP and NT-proBNP were not interchangeable. The mean BNP levels showed a 1.5 fold increase from CKD stage 3 to CKD stage 5 in those without SHF. In patients with SHF, a 2.5 fold increase was observed in BNP levels as the CKD stage progressed from CKD stage 3 to 5 . A marked rise in mean NTproBNP levels was noted in non-heart failure group and levels were three fold higher in CKD stage 5 compared to CKD stage 3. Similarly mean NT-proBNP levels were four times higher in CKD stage 5 compared to CKD stage 3 in patients with SHF.

\section{Receiver operator curve (ROC) analysis and recommended cutoffs}

The assays for BNP and NT-proBNP remained sensitive and specific among patients with impaired kidney function as indicated by the AUC (Figure 3). On ROC analysis the AUC for BNP and NT-proBNP was 0.7 (95\% CI $0.63-0.78, p$-value $<0.05)$ and $0.86(95 \%$ CI $0.81-$ $0.91, p$-value $<0.05$ ) respectively (Figure 4 ). Figure $4 \mathrm{~A}, \mathrm{~B}$

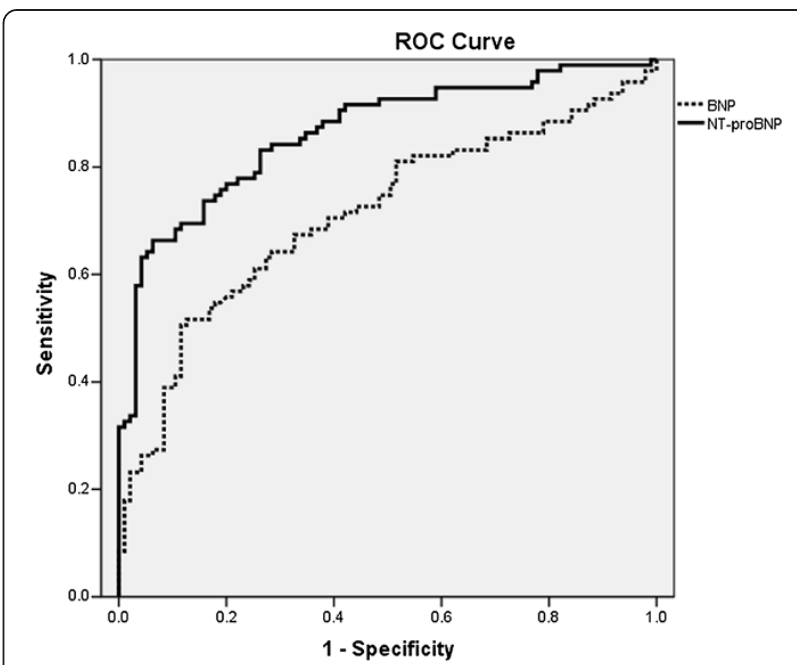

Figure 3 Entire study group ROC curve of BNP and NT-proBNP for heart failure. The area under the curve for BNP and NT-proBNP was 0.70 and 0.86 respectively.

and $\mathrm{C}$ shows the ROC analysis of BNP and NT-proBNP according to CKD stratification. The optimal cutoffs of BNP and NT-proBNP for diagnosing SHF for the entire study group and also according to CKD staging are shown in Tables 3 and 4.

\section{Discussion}

Multiple trials have reported that impaired kidney function augments the levels of these natriuretic peptides but the optimal cutoffs are not well known with various patients' population. This is the first study from this part of the world and adds to the clinical utility of these cardiac markers in specific renal population. The study population represents typical outpatients with known kidney dysfunction, a highly relevant population group to explore the utility of BNP and NT-proBNP as heart failure markers. Current study addressed the utility of BNP and NT-proBNP as heart failure markers in kidney patients. The results of this study are in concordance with previous studies and revealed an inverse relationship between kidney function and BNP $(r=-0.3)$ and NT-proBNP $(r=-0.5)[12,28-31]$. A head to head comparison between BNP and NT-proBNP revealed that NT-proBNP was much higher as compared to BNP in the SHF group and both values were not interchangeable. Using ROC analysis, the AUC for NT-proBNP was better than BNP in the entire study population, as well as in subgroups of CKD stages.

In this study group, plasma NT-proBNP levels were more affected by declining eGFR as compared to plasma BNP levels plus the optimal cut off for plasma NTproBNP in the diagnosis of SHF was markedly influenced by the severity of kidney dysfunction. A great deal of 

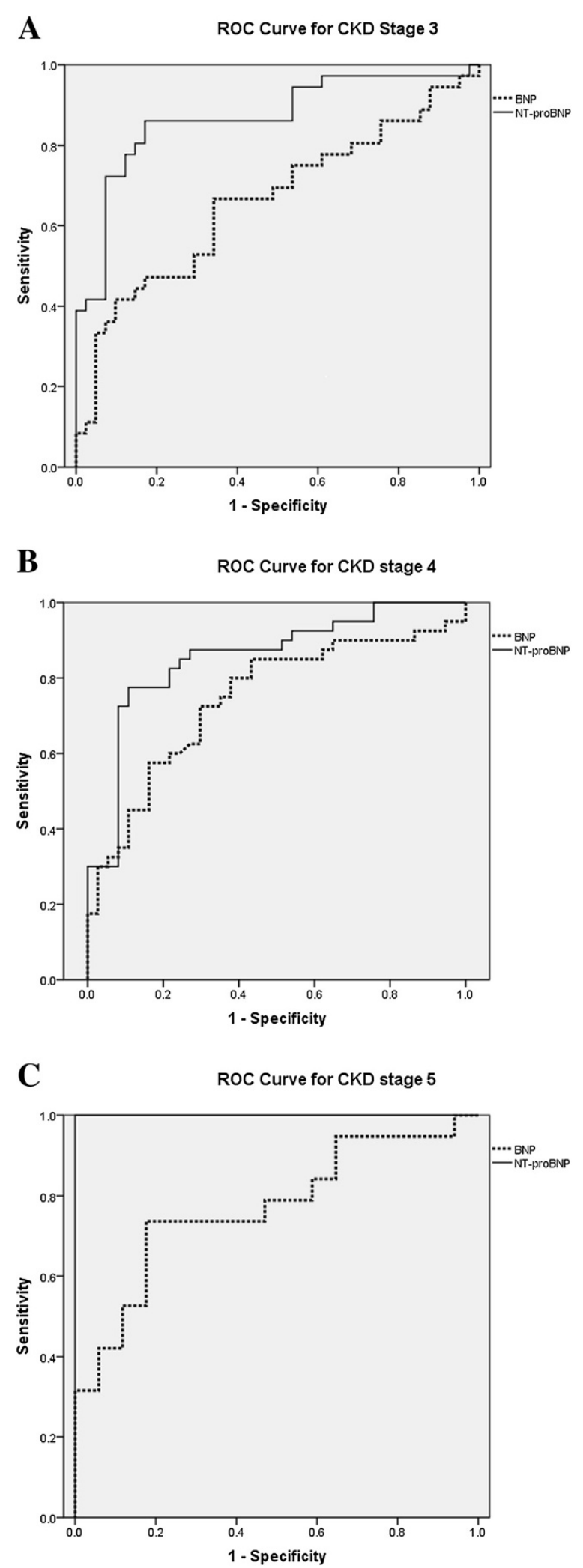

Figure 4 Receiver-operating characteristic (ROC) curves of BNP and NT-proBNP according to chronic kidney disease (CKD) staging. (A) For CKD stage 3 the area under the curve (AUC) for BNP and NT-proBNP was 0.66 and 0.88 respectively. (B) For CKD stage 4 the area under the curve (AUC) for BNP and NT-proBNP was 0.74 and 0.85 respectively. (C) For CKD stage 5 the area under the curve (AUC) for BNP and NT-proBNP was 0.77 and 1.00 respectively. 
Table 3 Potential BNP and NT-proBNP cut off levels for the assessment of systolic heart failure for all CKD subjects

\begin{tabular}{|c|c|c|c|c|c|c|}
\hline $\begin{array}{l}\text { Natriuretic } \\
\text { peptide }\end{array}$ & Group & $\begin{array}{c}\text { Optimal } \\
\text { cut } \\
\text { point } \\
\text { (pg/ml) }\end{array}$ & $\begin{array}{c}\text { Sensitivity } \\
\%\end{array}$ & $\begin{array}{c}\text { Specificity } \\
\%\end{array}$ & $\begin{array}{l}\text { Positive } \\
\text { likelihood } \\
\text { ratio }\end{array}$ & $\begin{array}{c}\text { Negative } \\
\text { likelihood } \\
\text { ratio }\end{array}$ \\
\hline BNP & Overall & 217 & 64.2 & 70 & 1.04 & 0.96 \\
\hline BNP & Overall & 254 & 61 & 75 & 1.14 & 0.90 \\
\hline BNP & Overall & 300 & 55 & 82.1 & 3.05 & 0.55 \\
\hline NT-proBNP & Overall & 799 & 91.6 & 52.6 & 1.99 & 0.16 \\
\hline NT-proBNP & Overall & 1536 & 84.2 & 71.6 & 4.13 & 0.30 \\
\hline NT-proBNP & Overall & 4502 & 73.7 & 82.1 & 4.17 & 0.30 \\
\hline
\end{tabular}

Abbreviations: BNP B-type natriuretic peptide, NT-proBNP amino terminal B-type natriuretic peptide, $A U C$ area under the curve, CKD chronic kidney disease.

controversy exists regarding the cut-off values of BNP and NT-proBNP levels in diagnosing SHF in patients with impaired kidney function. Generally the BNP and NTproBNP values $100 \mathrm{pg} / \mathrm{ml}$ and $125 \mathrm{pg} / \mathrm{ml}$ are considered abnormal and suggestive of heart failure as per manufacturers' product inserts. The strength of these markers is their capability to rule out the diagnosis of acute heart failure. In general, heart failure is unlikely at BNP values $<100 \mathrm{pg} / \mathrm{ml}$ and is very likely at BNP values $>500 \mathrm{pg} / \mathrm{ml}$ and, similarly, unlikely at NT-proBNP values $<300 \mathrm{pg} / \mathrm{ml}$ and very likely at NT-proBNP values $>450 \mathrm{pg} / \mathrm{ml}$ [32-34]. $\mathrm{McCullough}$ et al. previously reported an analysis from Breathing Not Properly Multinational Study in which BNP levels were found to be related to kidney function in patients with and without heart failure [35]. McCullough et al. reported that it would be appropriate to apply diagnostic value of approximately $200 \mathrm{pg} / \mathrm{ml}$ for BNP in those with eGFR $<60 \mathrm{ml} / \mathrm{min} / 1.73 \mathrm{~m}^{2}$. Jae Wong Yang et al. stated that heart failure could be diagnosed in patients with kidney dysfunction using BNP cut-off $858.5 \mathrm{pg} / \mathrm{ml}$ with $77 \%$ sensitivity and $72 \%$ specificity [36]. Anwaruddin et al. (PRIDE Study) noted that heart failure could be diagnosed with $89 \%$ sensitivity and $72 \%$ specificity using NT-proBNP cut-off of $1200 \mathrm{pg} / \mathrm{ml}$ in patient with eGFR

\begin{tabular}{|c|c|c|c|c|}
\hline $\begin{array}{l}\text { Natriuretic } \\
\text { peptide }\end{array}$ & Group & $\begin{array}{l}\text { Optimal cut } \\
\text { point }(\mathrm{pg} / \mathrm{ml})\end{array}$ & $\begin{array}{c}\text { Sensitivity } \\
\%\end{array}$ & $\begin{array}{c}\text { Specificity } \\
\%\end{array}$ \\
\hline BNP & Stage 3 CKD & 146 & 60 & 65.9 \\
\hline BNP & Stage 4 CKD & 309.4 & 60 & 78.4 \\
\hline BNP & Stage 5 CKD & 491 & 60 & 88.2 \\
\hline NT-proBNP & Stage 3 CKD & 1505.8 & 72.2 & 92.7 \\
\hline NT-proBNP & Stage 4 CKD & 7767.5 & 70 & 91.9 \\
\hline NT-proBNP & Stage 5 CKD & 11215.2 & 94.7 & 100 \\
\hline
\end{tabular}

Abbreviations: BNP B-type natriuretic peptide, NT-proBNP amino terminal B-type natriuretic peptide, $A \cup C$ area under the curve, $C K D$ chronic kidney disease.
$<60 \mathrm{ml} / \mathrm{min}$. It was reported that AUC for NT-proBNP in those with GFR $>60 \mathrm{ml} / \mathrm{min}$ was $0.95 \backslash$ for detecting heart failure however, among those with $\mathrm{GFR}<60 \mathrm{ml} / \mathrm{min}$ the NT-proBNP assay remained sensitive and specific with AUC of 0.88 [30]. AUC to detect heart failure tended to be greater for NT-proBNP than that for BNP in our study population.

Kidney dysfunction represents a variable that complicates the interpretation of BNP and NT-proBNP. As reported previously $[29,30,37,38]$, findings of this study propose that higher BNP and NT-proBNP cut-off points would be needed to diagnose SHF in patients with impaired kidney function. We propose BNP and NTproBNP cutoff levels of $300 \mathrm{pg} / \mathrm{ml}$ and $4502 \mathrm{pg} / \mathrm{ml} \mathrm{re-}$ spectively; for diagnosing SHF in patients with eGFR $<60 \mathrm{ml} / \mathrm{min}$. Luchner et al. demonstrated lower cut-offs; $125 \mathrm{pg} / \mathrm{ml}$ for BNP and $350 \mathrm{pg} / \mathrm{ml}$ for NT-proBNP in post-myocardial patients with renal dysfunction. The assay used for NT-proBNP by them was similar to the one used in current study (Roche diagnostics) but the mean eGFR in the impaired kidney function group was $71 \pm 12 \mathrm{ml} / \mathrm{min}$ and mostly included patients with mild renal dysfunction [31].

Our results show that NT-proBNP was more dependent on kidney function than BNP and but using a higher NT-proBNP cut-off had a better diagnostic accuracy than BNP. Given the high prevalence of left ventricular hypertrophy and left ventricular systolic dysfunction in patients with CKD, exclusion of heart failure becomes important in this population. In the present study half of the patients had SHF along with impaired kidney and has significant implications for use of natriuretic peptide assay. Both plasma BNP and NTproBNP levels correlated with NYHA symptom severity in patients with impaired kidney function. It has been consistently found in a large number of studies that BNP and NT-proBNP are elevated in patients with heart failure, and values were found to be related to disease severity as assessed by NYHA functional class $[39,40]$. Strong association was found between NT-proBNP 
levels and left ventricular hypertrophy and dysfunction in a recently reported large CKD cohort without heart failure. In the same study NT-proBNP improved the ability of clinical models to predict systolic dysfunction in CKD patients [41].

Overtly symptomatic patients $(n=28)$ in our study classified under NYHA class four had extremely high BNP and NT-proBNP levels (median 409.4 and $22520 \mathrm{pg} / \mathrm{ml}$ respectively). The biological activity of BNP includes diuresis, natriuresis, and inhibition of renin-angiotensin system, endothelin secretion, and systemic and renal sympathetic activity. Paradoxically, in congestive heart failure high BNP levels measured by conventional assays are associated with an absence of effect of this hormone [42]. The phenomena of 'endocrine paradox' of the heart are characterized by extremely high circulating levels of natriuretic peptides in heart failure patients, showing signs of fluid retention and vasoconstriction $[43,44]$. Some recent findings suggest that the commercially available immunoassay methods tend to progressively overestimate the real biological activity of the natriuretic peptides in patients with heart failure [45].

The studied population already suffered from impaired kidney function; hence duration of the disease may be a confounder in the current study. Ideally occult myocardial ischemia which raises BNP and NT-proBNP levels should have been excluded. Use of Cockcroft Gault equation to estimate GFR is controversial in Asians populations but good agreement between Cockcroft Gault and creatinine clearance has been observed in our setup [33]. Patients with CKD suffer from both systolic and diastolic heart failure but then in the current study patients with heart failure with preserved systolic function were not considered. Another limitation of the study is small sample size in subcategories of the data and further studies are required to reliably derive cutoffs. Differences exist in analytical performances of different BNP and MT-proBNP assays therefore it may be not right to suggest identical cut-off or decision values for all $\mathrm{BNP} /$ NT-proBNP immunoassays [46].

\section{Conclusion}

Product inserts by manufacturers of plasma BNP and NT-proBNP only have a single cut-off used in normal population and there is no mention of limitations of using them in patients with compromised renal function. The fact remains that many patients with heart failure also have renal insufficiency. Therefore, current study becomes very important in making clinicians aware of how to interpret the results in concomitant renal disease and also for kit manufacturers to include it in their product labeling. Both natriuretic peptides' assays can be used in patients with impaired kidney function but by using higher cutoffs stratified according to kidney dysfunction. NT-proBNP appears to predict SHF better than BNP. Kidney dysfunction makes the interpretation of these natriuretic peptides complicated. To improve the quality of care and subsequent prognosis, plasma BNP and especially NT-proBNP values should be interpreted in relation to the severity of kidney dysfunction.

\section{Ethical approval}

The study was given approval by the Ethical Review Committee of the Aga Khan University Hospital. Reference number: 1054-Path-ERC-08).

\section{Competing interests}

The authors declare that they have no competing interests.

\section{Authors' contributions}

$\sqcup J$ was involved in planning, patient recruitment, biochemical analysis, data analysis and write up of the manuscript, WK participated in patient selection and recruitment and review of manuscript, JT contributed in patient selection and recruitment and review of manuscript, IS was involved in project execution, data analysis and manuscript review, IA participated in design of study and statistical analysis of data, HS was involved in patient recruitment and FG proposed the initial idea, participated in its design, project execution and manuscript review. All authors read and approved the final manuscript.

\section{Funding}

This research was funded by the Departmental Seed Money Grant for research development (2008), The Aga Khan University (Project ID \# IS SM 080504). Guarantor: Dr. Farooq Ghani.

\section{Author details}

'Department of Pathology \& Microbiology, Aga Khan University, Stadium Road, P.O. Box 3500, Karachi 74800, Pakistan. ${ }^{2}$ Department of Medicine, Aga Khan University, Stadium Road, P.O. Box 3500, Karachi 74800, Pakistan. ${ }^{3}$ Department of Community Health Services, Aga Khan University, Stadium Road, P.O. Box 3500, Karachi 74800, Pakistan. ${ }^{4}$ Medical College Aga Khan University, Stadium Road, P.O. Box 3500, Karachi 74800, Pakistan.

Received: 2 November 2012 Accepted: 15 May 2013

Published: 31 May 2013

\section{References}

1. Coresh J, Astor BC, Greene T, Eknoyan G, Levey AS: Prevalence of chronic kidney disease and decreased kidney function in the adult US population: third national health and nutrition examination survey. Am J Kidney Dis 2003, 41(1):1-12.

2. Chadban SJ, Briganti EM, Kerr PG, Dunstan DW, Welborn TA, Zimmet PZ, Atkins RC: Prevalence of kidney damage in Australian adults: The AusDiab kidney study. J Am Soc Nephrol 2003, 14:S131-S138.

3. Zuo L, Ma YC, Zhou YH, Wang M, Xu GB, Wang HY: Application of GFRestimating equations in Chinese patients with chronic kidney disease. Am J Kidney Dis 2005, 45(3):463-472.

4. Coresh J, Selvin E, Stevens LA, Manzi J, Kusek JW, Eggers P, Van Lente F, Levey AS: Prevalence of chronic kidney disease in the United States. JAMA 2007, 298:2038-2047.

5. Jafar TH, Schmid CH, Levey AS: Serum creatinine as marker of kidney function in South Asians: a study of reduced GFR in adults in Pakistan. J Am Soc Nephrol 2005, 16(5):1413-1419.

6. King H, Aubert RE, Herman WH: Global burden of diabetes, 1995-2025: prevalence, numerical estimates, and projections. Diabetes Care 1998, 21(9):1414-1431.

7. Singh RB, Suh IL, Singh VP, Chaithiraphan S, Laothavorn P, Sy RG, Babilonia NA, Rahman AR, Sheikh S, Tomlinson B, Sarraf-Zadigan N: Hypertension 
and stroke in Asia: prevalence, control and strategies in developing countries for prevention. J Hum Hypertens 2000, 14:749-763.

8. Hameed K, Kadir M, Gibson T, Sultana S, Fatima Z, Syed A: The frequency of known diabetes, hypertension and ischaemic heart disease in affluent and poor urban populations of Karachi, Pakistan. Diabet Med 1995, 12(6):500-503.

9. Curtis BM, Parfrey PS: Congestive heart failure in chronic kidney disease: disease-specific mechanisms of systolic and diastolic heart failure and management. Cardiol Clin 2005, 23(3):275-284.

10. Wright SP, Doughty RN, Pearl A, Gamble GD, Whalley GA, Walsh HJ, Gordon G, Bagg W, Oxenham H, Yandle T, Richards M, Sharpe N: Plasma aminoterminal pro-brain natriuretic peptide and accuracy of heart-failure diagnosis in primary care: a randomized, controlled trial. J Am Coll Cardiol 2003, 42:1793-1800.

11. Shapiro BP, Chen HH, Burnett JC Jr, Redfield MM: Use of plasma brain natriuretic peptide concentration to aid in the diagnosis of heart failure. Mayo Clin Proc 2003, 78(4):481-486

12. McCullough PA, Duc P, Omland T, McCord J, Nowak RM, Hollander JE, Herrmann HC, Steg PG, Westheim A, Knudsen CW, Storrow AB, Abraham WT, Lamba S, Wu AHB, Perez A, Clopton P, Krishnaswamy P, Kazanegra R, Maisel AS: B-type natriuretic peptide and renal function in the diagnosis of heart failure: an analysis from the Breathing Not Properly Multinational Study. Am J Kidney Dis 2003, 41(3):571-579.

13. Dhar S, Pressman GS, Subramanian S, Kaul S, Gollamudi S, Bloom EJ, Figueredo VM: Natriuretic peptides and heart failure in the patient with chronic kidney disease: a review of current evidence. Postgrad Med J 2009, 85:299-302.

14. Clerico A, Giannoni A, Vittorini S, Passino C: Thirty years of the heart as an endocrine organ: physiological role and clinical utility of cardiac natriuretic hormones. Am J Physiol Heart Circ Physiol, 301(1):H12-H20.

15. Daniels LB, Maisel AS: Natriuretic peptides. J Am Coll Cardiol 2007 50(25):2357-2368.

16. Tonne JM, Campbell JM, Cataliotti A, Ohmine S, Thatava T, Sakuma T, Macheret F, Huntley BK, Burnett JC Jr, Ikeda Y: Secretion of glycosylated pro-B-type natriuretic peptide from normal cardiomyocytes. Clin Chem, 57:864-873.

17. Hama N, Itoh H, Shirakami G, Nakagawa O, Suga S, Ogawa Y, Masuda I, Nakanishi K, Yoshimasa T, Hashimoto Y: Rapid ventricular induction of brain natriuretic peptide gene expression in experimental acute myocardial infarction. Circulation 1995, 92:1558-1564.

18. Soleilhac JM, Lucas E, Beaumont A, Turcaud S, Michel JB, Ficheux D, Fournie-Zaluski MC, Roques BP: A 94-kDa protein, identified as neutral endopeptidase-24.11, can inactivate atrial natriuretic peptide in the vascular endothelium. Mol Pharmacol 1992, 41:609-614.

19. Vanderheyden M, Bartunek J, Goethals M: Brain and other natriuretic peptides: molecular aspects. Eur J Heart Fail 2004, 6(3):261-268

20. Chen HH, Burnett JC Jr: The natriuretic peptides in heart failure: diagnostic and therapeutic potentials. Proc Assoc Am Physicians 1999, 111(5):406-416.

21. McCullough PA, Omland T, Maisel AS: B-type natriuretic peptides: a diagnostic breakthrough for clinicians. Rev Cardiovasc Med 2003, 4(2):72-80.

22. Levin ER, Gardner DG, Samson WK: Natriuretic peptides. N Engl J Med 1998, 339(5):321-328.

23. Cockcroft DW, Gault MH: Prediction of creatinine clearance from serum creatinine. Nephron 1976, 16(1):31-41.

24. K/DOQI clinical practice guidelines for chronic kidney disease: evaluation, classification, and stratification. Am J Kidney Dis 2002, 39(2 Suppl 1):S1-S266.

25. Dickstein K, Cohen-Solal A, Filippatos G, McMurray JJ, Ponikowski P, PooleWilson PA, Stromberg A, van Veldhuisen DJ, Atar D, Hoes AW, Keren A, Mebazaa A, Nieminen M, Priori SG, Swedberg K: ESC Guidelines for the diagnosis and treatment of acute and chronic heart failure 2008: the Task Force for the Diagnosis and Treatment of Acute and Chronic Heart Failure 2008 of the European Society of Cardiology. Developed in collaboration with the Heart Failure Association of the ESC (HFA) and endorsed by the European Society of Intensive Care Medicine (ESICM). Eur Heart J 2008, 29(19):2388-2442.

26. Maffei S, Del Ry S, Prontera C, Clerico A: Increase in circulating levels of cardiac natriuretic peptides after hormone replacement therapy in postmenopausal women. Clin Sci (Lond) 2001, 101(5):447-453.

27. Karjalainen AH, Ruskoaho H, Vuolteenaho O, Heikkinen JE, Backstrom AC, Savolainen MJ, Kesaniemi YA: Effects of estrogen replacement therapy on natriuretic peptides and blood pressure. Maturitas 2004, 47:201-208.
28. Luchner A, Hengstenberg C, Lowel H, Buchner S, Schunkert H, Riegger GA, Holmer S: NT-ProBNP in outpatients after myocardial infarction: interaction between symptoms and left ventricular function and optimized cut-points. J Card Fail 2005, 11:S21-27.

29. deFilippi CR, Seliger SL, Maynard S, Christenson RH: Impact of renal disease on natriuretic peptide testing for diagnosing decompensated heart failure and predicting mortality. Clin Chem 2007, 53(8):1511-1519.

30. Anwaruddin S, Lloyd-Jones DM, Baggish A, Chen A, Krauser D, Tung R, Chae C, Januzzi JL Jr: Renal function, congestive heart failure, and aminoterminal pro-brain natriuretic peptide measurement: results from the ProBNP Investigation of Dyspnea in the Emergency Department (PRIDE) Study. J Am Coll Cardiol 2006, 47:91-97.

31. Luchner A, Hengstenberg C, Lowel H, Riegger GA, Schunkert H, Holmer S: Effect of compensated renal dysfunction on approved heart failure markers: direct comparison of brain natriuretic peptide (BNP) and N-terminal pro-BNP. Hypertension 2005, 46(1):118-123.

32. Felker GM, Petersen JW, Mark DB: Natriuretic peptides in the diagnosis and management of heart failure. CMAJ 2006, 175(6):611-617.

33. National Clinical Guideline Centre (UK): Chronic Heart Failure: National Clinical Guideline for Diagnosis and Management in Primary and Secondary Care: Partial Update [Internet]. London: Royal College of Physicians (UK); 2010. (NICE Clinical Guidelines, No. 108.) Available from: http://www.ncbi. nlm.nih.gov/books/NBK65340/.

34. Jessup M, Abraham WT, Casey DE, Feldman AM, Francis GS, Ganiats TG, Konstam MA, Mancini DM, Rahko PS, Silver MA, Stevenson LW, Yancy CW: 2009 focused update: ACCF/AHA Guidelines for the Diagnosis and Management of Heart Failure in Adults: a report of the American College of Cardiology Foundation/American Heart Association Task Force on Practice Guidelines: developed in collaboration with the International Society for Heart and Lung Transplantation. Circulation 2009, 119:1977-2016.

35. McCullough PA, Kuncheria J, Mathur VS: Diagnostic and therapeutic utility of B-type natriuretic peptide in patients with renal insufficiency and decompensated heart failure. Rev Cardiovasc Med. 2003, 4(Suppl 7):S3-S12.

36. Yang JW, Kim MS, Kim JS, Yoo JM, Han ST, Kim BR, Kim YD, Choi SO, Han BG: Relationship between serum brain natriuretic peptide and heart function in patients with chronic kidney disease. Korean J Intern Med 2008, 23:191-200.

37. McCullough PA, Nowak RM, McCord J, Hollander JE, Herrmann HC, Steg PG, Duc P, Westheim A, Omland T, Knudsen CW: B-type natriuretic peptide and clinical judgment in emergency diagnosis of heart failure: analysis from Breathing Not Properly (BNP) Multinational Study. Circulation 2002, 106:416-422.

38. Ouanes I, Jalloul F, Ayed S, Dachraoui F, Ouanes-Besbes L, Fekih Hassen M, Elatrous S, Abroug F: N-terminal proB-type natriuretic peptide levels aid the diagnosis of left ventricular dysfunction in patients with severe acute exacerbations of chronic obstructive pulmonary disease and renal dysfunction. Respirology, 17:660-666.

39. Zhao XY, Yang YJ, Zhang J, Kang LM, Wei BQ, Gao XJ, Lu R, Zhang CL: Association of plasma amino-terminal pro-A-, B- and C-type natriuretic peptide levels with NYHA grade and echocardiographic derived parameters of cardiac function in heart failure patients. Zhonghua Xin Xue Guan Bing Za Zhi 2009, 37:486-490.

40. Nagaya N, Nishikimi T, Okano Y, Uematsu M, Satoh T, Kyotani S, Kuribayash S, Hamada S, Kakishita M, Nakanishi N, Takamiya M, Kunieda T, Matsuo H, Kangawa K: Plasma brain natriuretic peptide levels increase in proportion to the extent of right ventricular dysfunction in pulmonary hypertension. J Am Coll Cardiol 1998, 31:202-208.

41. Mishra RK, Li Y, Ricardo AC, Yang W, Keane M, Cuevas M, Christenson R, deFilippi C, Chen J, He J, Kallem RR, Raj DS, Schelling JR, Wright J, Go AS, Shlipak MG: Association of N-terminal pro-B-type natriuretic peptide with left ventricular structure and function in chronic kidney disease (from the Chronic Renal Insufficiency Cohort [CRIC]). Am J Cardiol, 111:432-438.

42. Tsutamoto T, Wada A, Maeda K, Hisanaga T, Maeda Y, Fukai D, Ohnishi M, Sugimoto Y, Kinoshita M: Attenuation of compensation of endogenous cardiac natriuretic peptide system in chronic heart failure: prognostic role of plasma brain natriuretic peptide concentration in patients with chronic symptomatic left ventricular dysfunction. Circulation 1997, 96:509-516.

43. Goetze JP, Kastrup J, Rehfeld JF: The paradox of increased natriuretic hormones in congestive heart failure patients: does the endocrine heart also fail in heart failure? Eur Heart J 2003, 24(16):1471-1472. 
44. Goetze JP: Biochemistry of pro-B-type natriuretic peptide-derived peptides: the endocrine heart revisited. Clin Chem 2004, 50(9):1503-1510.

45. Chen HH: Heart failure: a state of brain natriuretic peptide deficiency or resistance or both! J Am Coll Cardiol. 2007, 49(10):1089-1091.

46. Clerico A, Zaninotto M, Prontera C, Giovannini S, Ndreu R, Franzini M, Zucchelli GC, Plebani M: State of the art of BNP and NT-proBNP immunoassays: the CardioOrmoCheck study. Clin Chim Acta, 414:112-119.

doi:10.1186/1471-2369-14-117

Cite this article as: Jafri et al:: B-type natriuretic peptide versus amino

terminal pro-B type natriuretic peptide: selecting the optimal heart

failure marker in patients with impaired kidney function. $B M C$

Nephrology 2013 14:117.

\section{Submit your next manuscript to BioMed Central and take full advantage of:}

- Convenient online submission

- Thorough peer review

- No space constraints or color figure charges

- Immediate publication on acceptance

- Inclusion in PubMed, CAS, Scopus and Google Scholar

- Research which is freely available for redistribution 